\title{
TINGKAT KESEJAHTERAAN PETANI SAYURAN ORGANIK DI KECAMATAN KEDUNGBANTENG KABUPATEN BANYUMAS
}

\author{
The Level of Welfare of Organic Vegetable Farmers in Kedungbanteng Sub District, \\ Banyumas District
}

\author{
Nur Istia Utami*, Indah Widyarini, dan Ratna Satriani \\ Program Studi Agribisnis, Fakultas Pertanian Universitas Jenderal Soedirman
}

Alamat Korespondensi: nuristiautami@gmail.com

\begin{abstract}
ABSTRAK
Kecamatan Kedungbanteng merupakan daerah sentra produksi sayuran organik di Kabupaten Banyumas dengan lokasi yang tepat yaitu dataran tinggi, sehingga cocok untuk memproduksi sayuran organik. Hasil produksi yang relatif rendah menyebabkan keuntungan yang diperoleh petani juga rendah dan menyebabkan rendahnya nilai tukar petani. Harga jual petani untuk produk sayur organik masih rendah, petani sayur organik di Kedungbanteng hingga saat ini belum memperoleh keuntungan maksimal dalam kegiatan usahataninya. Umumnya sayur organik memiliki harga jual lebih tinggi yang memberikan tingkat pendapatan tinggi dan memenuhi kemampuan petani dalam kebutuhan dasarnya untuk mencapai kesejahteraan rumah tangga petani. Penelitian ini bertujuan untuk mengetahui: 1) pendapatan yang diterima petani dalam usahatani sayuran organik dan kontribusinya terhadap pendapatan total rumah tangga petani; 2) distribusi pendapatan petani; 3) tingkat kesejahteraan rumah tangga petani sayuran organik di Kecamatan Kedungbanteng. Penelitian dilaksanakan di desa Melung dan desa Windujaya kecamatan Kedungbanteng pada bulan September hingga Oktober 2019. Metode penelitian yang digunakan adalah metode survei. Penentuan responden menggunakan metode sensus diperoleh 18 orang petani sayur organik. Analisis yang digunakan yaitu analisis pendapatan usahatani, analisis kontribusi pendapatan, analisis distribusi pendapatan, dan analisis tingkat kesejahteraan. Hasil penelitian menunjukkan bahwa: 1) besar pendapatan usahatani yang diterima petani yaitu Rp7.892.252,00 per tahun dan kontribusi pendapatan usahatani sayuran organik terhadap pendapatan total yaitu 20,23\%;2) tingkat pemerataan pendapatan petani sayuran organik di kecamatan Kedungbanteng termasuk dalam ketimpangan yang tinggi yaitu pendapatan petani yang tidak merata dengan nilai Gini Ratio 0,86; 3) tingkat kesejahteraan rumah tangga petani sayuran organik di kecamatan Kedungbanteng masuk kedalam kategori sejahtera dengan NTPRP 3,55.
\end{abstract}

Kata kunci: distribusi pendapatan, kesejahteraan, kontribusi pendapatan, pendapatan, petani sayur organik

\section{ABSTRACT}

Kedungbanteng District is an area of organic vegetable production centers in Banyumas Regency with the right location, namely the highlands so it is very suitable for producing organic vegetables. The relatively low production results cause the profits obtained by farmers are also low and cause low exchange rates of farmers. The selling price of farmers for organic vegetable products is still low, organic vegetable farmers in Kedungbanteng have yet to get maximum profit in their farming activities. Generally organic vegetables have a higher selling price that provides a high level of income and meets the ability of farmers in their basic needs to achieve the welfare of the farmer's household. This study aims to determine: 1) the income received by farmers in organic vegetable farming and its contribution to total household income of farmers; 2) distribution of farmers' income; 3) the level of household welfare of organic vegetable farmers in Kedungbanteng District. This research was conducted in Melung and Windujaya villages, Kedungbanteng sub-district in September to October 2019. The research method used was a survey method. Determination of respondents using the census method obtained by 18 organic vegetable farmers. The analysis used is farm income analysis, income contribution analysis, income distribution analysis, and welfare level analysis. The result show that: 1) organic vegetable farming income received by farmers is Rp7.892.252,00/year and its contribution to total income is 20.23 percent; 2) the income distribution of organic vegetable farmers in Kedungbanteng sub district is high; 3) Organic vegetable farming households in Kedungbanteng sub district are relatively prosperous.

Keywords: income, income contribution, income distribution, organic vegetable farmers, welfare 


\section{PENDAHULUAN}

Produk pertanian organik memiliki kelebihan dalam penerapan sistem produksi yang berprinsip ramah terhadap lingkungan dan memiliki keamanan untuk dikonsumsi serta produk pertanian organik memiliki kandungan nutrisi tinggi (Sutarni, 2017). Usahatani sayuran organik masih dikembangkan di kecamatan Kedungbanteng dengan lokasi yang tepat yaitu dataran tinggi sehingga sangat cocok untuk memproduksi sayuran organik. Menurut Sukayat (2017), secara topografi usaha di bidang pertanian di dataran tinggi lebih mengutamakan tanaman sayuran dan atau tahunan.

Hasil produksi yang relatif rendah menyebabkan keuntungan yang diperoleh petani juga rendah. Hal demikian menyebabkan nilai tukar petani yang rendah dan petani belum bisa memenuhi kebutuhan sehari-hari. Selanjutnya harga jual yang masih rendah untuk produk sayur organik, yang seharusnya sayur organik memiliki harga lebih tinggi dibanding sayur non organik. Menurut Khorniawati (2014), harga produk pertanian organik lebih mahal dikarenakan banyak petani yang lebih memilih pertanian konvensional daripada pertanian organik. Hal ini dikarenakan pertanian organik tidak menggunakan pestisida, pupuk kimia dan sejenisnya pada masa produksinya, sehingga resiko untuk mengalami kerugian seperti gagal panen lebih besar daripada pertanian konvensional. Harga jual dan nilai tukar petani yang tinggi akan memberikan pendapatan petani yang tinggi serta kesejahteraan pada petani sayur organik. Namun, petani sayur organik di Kedungbanteng merasa hingga saat ini belum memperoleh keuntungan yang maksimal dalam kegiatan usahataninya. Kondisi tersebut akan mempengaruhi tingkat pendapatan dan kemampuan petani dalam memenuhi kebutuhan dasarnya untuk mencapai kesejahteraan rumah tangga petani.

Berdasarkan uraian tersebut, tujuan penelitian ini adalah untuk: 1) mengetahui seberapa besar pendapatan yang diterima petani dan kontribusi pendapatan usahatani sayuran organik terhadap pendapatan total rumah tangga petani di kecamatan Kedungbanteng; 2) mengetahui distribusi pendapatan petani sayuran organik di kecamatan Kedungbanteng; 3) mengetahui tingkat kesejahteraan rumah tangga petani sayuran organik di kecamatan Kedungbanteng.

\section{METODE PENELITIAN}

Metode yang digunakan dalam penelitian ini yaitu metode survei. Penelitian dilaksanakan di desa Melung dan desa Windujaya kecamatan Kedungbanteng, dengan pertimbangan karena hanya dua desa tersebut yang 
mengusahakan sayuran organik di kecamatan Kedungbanteng, kabupaten Banyumas. Penelitian dilaksanakan pada bulan September hingga Oktober 2019. Sasaran dalam penelitian ini adalah petani sayur organik di desa Melung dan desa Windujaya Kecamatan Kedungbanteng, Kabupaten Banyumas. Responden yang diambil dalam penelitian ini yaitu semua petani sayur organik yang ada di Kecamatan Kedungbanteng, kabupaten Banyumas.

Analisis data yang digunakan pada penelitian ini adalah:

\section{Analisis Pendapatan Usahatani}

Pendapatan usahatani adalah selisih antara penerimaan dan semua biaya. Untuk menghitung pendapatan usahatani digunakan rumus:

$$
\mathrm{NR}=\mathrm{TR}-\mathrm{TC}
$$

Keterangan:

$\mathrm{NR}=$ Net revenue (pendapatan atau keuntungan)

$\mathrm{TR}=$ Total revenue (penerimaan total)

$\mathrm{TC}=$ Total cost (biaya total)

TR (Total Revenue) merupakan penerimaan usahatani yang diperoleh dari perkalian antara produksi yang diperoleh dengan harga jual. Pernyataan ini dapat dituliskan:

$$
\mathrm{TR}=\mathrm{P} \times \mathrm{Q}
$$

Keterangan:

$\mathrm{TR}=$ Total revenue (total penerimaan)

$\mathrm{P} \quad=$ Price (harga)
$\mathrm{Q}=$ Quantity (jumlah produk) Analisis biaya

TC ( Total cost) merupakan biaya total yang terdiri atas biaya tetap (fixed cost) dan biaya tidak tetap (variable cost). Biaya tetap sebagai biaya yang relatif tetap jumlahnya, dan terus dikeluarkan walaupun produksi yang diperoleh banyak atau sedikit. Biaya tidak tetap atau biaya variabel sebagai biaya yang besar kecilnya dipengaruhi oleh produksi yang diperoleh. Untuk menghitung total biaya usahatani digunakan rumus:

$$
\mathrm{TC}=\mathrm{FC}+\mathrm{VC}
$$

Keterangan:

$\mathrm{TC}=$ Total Cost (total biaya)

$\mathrm{FC}=$ Fixed Cost (biaya tetap)

$\mathrm{VC}=$ Variable Cost (biaya variabel)

2. Analisis Kontribusi Pendapatan

Analisis kontribusi pendapatan diperoleh dengan cara membandingkan antara pendapatan masing-masing usaha dengan pendapatan total keluarga petani sayuran organik dikalikan $100 \%$ yaitu dengan rumus :

$$
\text { Kontribusi }(\%)=\frac{P d i}{T P d} \times 100 \%
$$

Keterangan:

$$
\begin{aligned}
P d i= & \text { Pendapatan Usahatani Sayuran } \\
& \text { Organik }(\mathrm{Rp}) \\
T P d= & \text { Total Pendapatan }(\mathrm{Rp})
\end{aligned}
$$

TPd (Total Pendapatan) diperoleh dari penjumlahan antara pendapatan usahatani sayuran organik, pendapatan usahatani diluar sayuran organik, dan 
pendapatan diluar usahatani atau dapat dirumuskan:

$$
T P d=P d i+P d j+P d l
$$

Keterangan:

$P d i=$ Pendapatan usahatani sayuran organik (Rp)

$P d j=$ Pendapatan usahatani diluar sayuran organik (Rp)

$P d l=$ Pendapatan diluar usahatani (Rp)

3. Analisis Distribusi Pendapatan

a. Gini Ratio

Metode yang digunakan untuk mengukur tingkat ketimpangan distribusi pendapatan rumah tangga petani sayur organik di kecamatan Kedungbanteng, kabupaten Banyumas yaitu dengan Gini Ratio (Indeks Gini). Berikut penilaian tinggi rendahnya ketimpangan distribusi pendapatan tersebut dilakukan dengan kriteria antara lain:

a) Indeks Gini kurang dari 0,4 menunjukkan ketimpangan distribusi pendapatan yang rendah.

b) Indeks Gini antara 0,4-0,5 menunjukkan ketimpangan distribusi pendapatan sedang.

c) Indeks Gini lebih besar atau sama dengan 0,5 menunjukkan ketimpangan distribusi pendapatan yang tinggi. Makin mendekati nol berarti makin baik distribusinya, sebaliknya makin mendekati satu, distribusi pendapatan makin buruk atau timpang.
Rumus yang digunakan untuk menghitung nilai Gini menurut Badan Pusat Statistik (2019), yaitu:

$$
G R=1-\sum_{i=1}^{n} f_{p i} x\left(F c_{i}+F c_{i-1}\right)
$$

Keterangan:

GR $=$ koefisien gini

$\mathrm{F}_{p i}=$ frekuensi penduduk dalam kelas pengeluaran ke-i
$\mathrm{Fc}_{i}=$ frekuensi kumulatif dari total pengeluaran dalam kelas pengeluaran ke-i
$\mathrm{Fc}_{i-1}=$ frekuensi kumulatif dari total pengeluaran dalam kelas pengeluaran ke-(i-1)

b. Kurva Lorentz

Kurva Lorentz menggambarkan distribusi kumulatif pendapatan nasional di kalangan lapisan-lapisan penduduk. Kurva ini terletak di dalam sebuah bujur sangkar yang sisi tegaknya melambangkan persentase kumulatif pendapatan nasional, sedangkan sisi datarnya mewakili persentase kumulatif penduduk. Kurvanya sendiri ditempatkan pada diagonal utama bujur sangkar tersebut, semakin dekat ke diagonal (semakin lurus) artinya distribusi pendapatan semakin merata. Sebaliknya, jika kurva semakin jauh dari diagonal (semakin lengkung), maka mencerminkan keadaan yang semakin buruk, distribusi pendapatan nasional semakin timpang dan tidak merata (Gambar 1). Indikator kurva Lorentz yaitu:

a) Semakin dekat dengan diagonal, semakin merata pendapatan 
b) Semakin jauh dengan diagonal, semakin tidak merata pendapatan

4. Analisis Tingkat Kesejahteraan

Pengukuran tingkat kesejahteraan rumah tangga petani sayur organik menggunakan Nilai Tukar Pendapatan Rumah Tangga Petani (NTPRP) merupakan nisbah antara pendapatan total rumah tangga dengan pengeluaran total rumah tangga. Pendapatan total rumah tangga pertanian merupakan penjumlahan dari seluruh nilai hasil produksi komoditas pertanian yang dihasilkan petani, nilai dari berburuh tani, nilai hasil produksi usaha non pertanian, nilai dari berburuh non pertanian, dan lainnya. Sedangkan pengeluaran petani merupakan penjumlahan dari pengeluaran untuk konsumsi rumah tangga dan pengeluaran untuk biaya produksi usaha tani (Keumala, 2018).
Secara matematis konsep Nilai Tukar Pendapatan Rumah Tangga Petani sebagai berikut:

$$
\begin{aligned}
& \text { NTPRP : Y/E } \\
& \mathrm{Y}=\mathrm{Yp}+\mathrm{Ynp} \\
& \mathrm{E}=\mathrm{Ep}+\mathrm{Ek}
\end{aligned}
$$

Dimana:

$$
\begin{aligned}
\text { NTPRP }= & \text { Nilai Tukar Pendapatan Rumah } \\
& \text { tangga Petani } \\
= & \text { Pendapatan } \\
\mathrm{Y}= & \text { Pengeluaran } \\
\mathrm{E} \quad & \text { Total pendapatan dari usaha } \\
\mathrm{Yp} \quad \text { pertanian } & \\
\mathrm{Ynp}= & \text { Total pendapatan dari non } \\
& \text { pertanian } \\
\mathrm{Ep} \quad & \begin{array}{l}
\text { Total pengeluaran untuk usaha } \\
\text { pertanian }
\end{array} \\
\mathrm{Ek} \quad & \text { Total pengeluaran untuk usaha } \\
& \text { non pertanian. }
\end{aligned}
$$

Apabila,

a) $\mathrm{NTPRP}<1$, maka rumah tangga petani belum sejahtera, dan

b) NTPRP $>1$, maka rumah tangga petani sudah sejahtera.

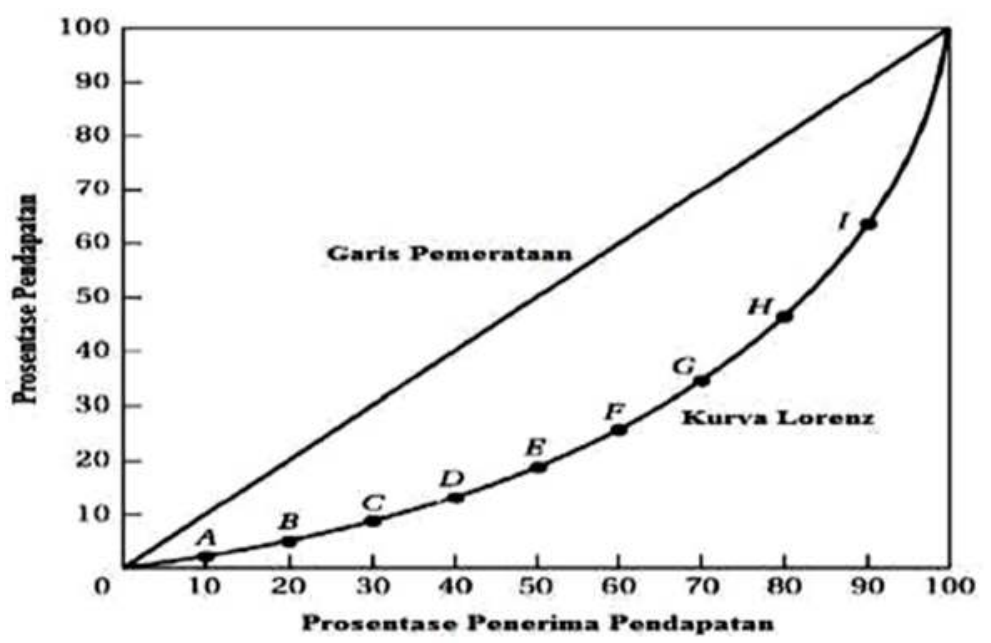

Gambar 1. Kurva Lorentz 


\section{HASIL DAN PEMBAHASAN}

\section{Pendapatan Usahatani}

Pendapatan merupakan selisih antara penerimaan dan semua biaya, keuntungan atau profit merupakan pendapatan yang diterima dikurangi dengan biaya-biaya yang dikeluarkan. Menurut Shinta (2011), penerimaan usahatani adalah perkalian antara produksi yang dihasilkan dengan harga jual. Keuntungan usahatani adalah selisih antara penerimaan dan semua biaya. Penerimaan, biaya dan pendapatan usahatani sayur organik di kecamatan Kedungbanteng dapat dilihat pada Tabel 1.

Tabel 1 menunjukkan penerimaan yang diperoleh petani rata-rata $\mathrm{Rp}$ 8.565.528,00 per tahun dengan total biaya usahatani sebesar Rp 673.276,00 per tahun. Jenis sayur yang dihasilkan diantaranya yaitu kangkung, caisim, pakcoy, kailan, brokoli, kol, bawang daun, selada, sawi, bayam, bayam merah, seledri, kacang panjang, buncis, leunca, terong, tomat, labu siam, terong, dan cabai. Periode penanaman dari hasil produksi sayur organik tersebut yaitu bulan November 2018 hingga Oktober 2019. Harga jual sayur organik tersebut bervariasi yaitu mulai dari harga $\mathrm{Rp}$ $3.000,00 / \mathrm{kg}$ hingga Rp 65.000,00/kg. Harga paling rendah ada pada sayur labu siam organik yaitu $\mathrm{Rp} 3.000,00 / \mathrm{kg}$ dan harga tertinggi yaitu sayur brokoli organik sebesar Rp 65.000,00/kg. Harga yang bervariasi tersebut dikarenakan pemasaran hasil produksi dari petani yang berbeda-beda, yaitu ada yang menjual kepada tengkulak, ke supermarket maupun menjual langsung ke konsumen di GOR Satria Purwokerto setiap hari Minggu. Selain itu, harga yang bervariasi juga dipengaruhi oleh harga pasar yang berubah-ubah.

Menurut Minarni (2017), sayuran organik secara ekonomis mempunyai harga yang lebih tinggi dibandingkan harga sayuran non organik. Harga sayuran organik di beberapa supermarket di kabupaten Banyumas untuk kangkung dan bayam sekitar Rp 6.000/250 g, sedangkan untuk caisin dan selada sekitar Rp $8.000 / 250 \mathrm{~g}$.

Tabel 1. Pendapatan usahatani sayuran organik di kecamatan Kedungbanteng

\begin{tabular}{lc}
\hline \multicolumn{1}{c}{ Uraian } & Rata-rata $(\mathrm{Rp} / \mathrm{th})$ \\
\hline Total Penerimaan & 8.565 .528 \\
\hline Biaya & \\
Benih & 355.489 \\
Pupuk & 180.556 \\
Pengemasan & 25.000 \\
Transportasi & 93.333 \\
Sewa Lahan & 18.898 \\
\hline Total Biaya & 673.276 \\
\hline Total Pendapatan & 7.892 .252 \\
\hline
\end{tabular}

Sumber : Data primer diolah, 2019. 
Biaya yang dikeluarkan petani yaitu biaya untuk benih, pupuk, pengemasan, transportasi, dan sewa lahan. Biaya paling besar dikeluarkan petani rata-rata merupakan biaya benih yaitu sebesar Rp $355.489,00$ per tahun. Benih yang digunakan oleh petani tersebut sebagian besar merupakan benih kemasan yang dibeli di pasar toko pertanian, yaitu menggunakan benih kemasan merk "panah merah". Biaya terbesar kedua ada pada biaya pupuk sebesar Rp 180.556,00 per tahun. Jenis pupuk organik yang biasa digunakan oleh petani yaitu pupuk kandang (kotoran kambing dan ayam), tetapi ada juga petani yang menggunakan urin kelinci, merang padi, dan pupuk cair organik (EM4). Biaya pengemasan sebesar Rp 25.000,00 per tahun. Petani mengeluarkan biaya pengemasan yaitu sebagai pengemas sayur organik yang akan dijual ke supermarket maupun ke GOR Satria Purwokerto berupa plastik dan isolasi. Biaya transportasi yang dikeluarkan petani merupakan biaya untuk mendistribusikan sayuran organik ke pasar tujuan yaitu Purwokerto. Namun, tidak semua petani mengeluarkan biaya pengemasan dan transportasi. Petani yang mengeluarkan biaya pengemasan dan transpotasi hanya tiga petani, karena sebagian besar petani menjual produk sayur organiknya kepada tengkulak yang tidak membebani biayabiaya tersebut.
Pendapatan dapat dihitung dari selisih antara total penerimaan dengan total biaya yang dikeluarkan pada usahatani sayur organik. Sehingga, dapat dihitung pendapatan rata-rata petani dalam mengusahakan usahatani sayur organik di kecamatan Kedungbanteng sebesar Rp 7.892.252,00 per tahun. Artinya, tiap petani rata-rata memperoleh pendapatan sebesar Rp 659.263,00 per bulan dengan luas lahan rata-rata 445,8 $\mathrm{m}^{2}$. Pendapatan dapat ditingkatkan dengan upaya peningkatan posisi tawar petani yang dapat dilakukan dengan penguatan kelembagaan petani. Melalui kelembagaan ini, petani merencanakan proses produksi dan pemasaran secara kolektif sehingga tercapai efisiensi biaya dan menaikkan posisi tawar petani dalam sistem usaha pertanian, upaya penguatan kelembagaan petani perlu dukungan dari seluruh pihak (Wahyuni, 2017).

\section{Kontribusi Pendapatan Usahatani}

Kontribusi adalah besarnya sumbangan yang diberikan dari suatu kegiatan atau pekerjaan terhadap pendapatan keluarga (Yulida, 2012). Petani di kecamatan Kedungbanteng selain memperoleh pendapatan dari usahatani sayuran organik, petani memperoleh pendapatan lain dari kegiatan usahatani selain sayur organik dan pendapatan diluar usahatani (non usahatani). Menurut Bhastoni (2015), analisis kontribusi 
pendapatan bertujuan untuk mengetahui berapa besar persentase atau proporsi pendapatan yang diperoleh dari kegiatan usahatani atau dari kegiatan non usahatani. Pendapatan total rumah tangga diperoleh dengan menjumlahkan pendapatan setiap anggota keluarga yang bekerja dari usahatani dan pendapatan non usahatani baik yang berasal dari sektor pertanian maupun sektor non pertanian. Kontribusi pendapatan petani sayur organik di kecamatan Kedungbanteng dapat dilihat pada Tabel 2.

Tabel 2 menunjukkan pendapatan usahatani sayur organik di kecamatan Kedungbanteng menyumbangkan pendapatan rata-rata sebesar 20,23 persen dari total pendapatan rumah tangga.
Usahatani diluar sayuran organik menyumbangkan pendapatan rumah tangga sebesar 31,91 persen, jenis pekerjaan tersebut diantaranya buruh tani dan pedagang tanaman hias. Sedangkan pendapatan diluar usahatani paling besar kontribusinya terhadap pendapatan total rumah tangga yaitu rata-rata sebesar 47,86 persen. Jenis pekerjaan dari keluarga petani diluar usahatani meliputi buruh, karyawan wisata, karyawan swasta, wiraswasta, penjual barang bekas, asisten rumah tangga, dan peternak ayam. Menurut Wardie (2015), berbagai jenis pekerjaan tersebut terkait dengan upaya untuk memaksimalkan potensi kerja yang dimiliki sehingga pada akhirnya dapat meningkatkan pendapatan keluarganya.

Tabel 2. Kontribusi pendapatan petani sayuran organik di kecamatan Kedungbanteng

\begin{tabular}{lcc}
\hline \multicolumn{1}{c}{ Sumber Pendapatan } & Rata-rata Pendapatan $(\mathrm{Rp} / \mathrm{th})$ & Kontribusi $(\%)$ \\
\hline Usahatani Sayur Organik & 7.892 .252 & 20,23 \\
Usahatani diluar Sayur Organik & 12.446 .667 & 31,91 \\
Luar Usahatani & 18.666 .667 & 47,86 \\
\hline Total Pendapatan & 39.005 .586 & 100,00 \\
\hline
\end{tabular}

Sumber: Data primer diolah, 2019.

Tabel 3. Nilai koefisien Gini responden di kecamatan Kedungbanteng

\begin{tabular}{|c|c|c|c|c|c|c|c|}
\hline \multirow[b]{2}{*}{ Uraian } & \multirow[b]{2}{*}{$\begin{array}{c}\text { Total } \\
\text { Pendapatan } \\
\text { Petani } \\
\text { Sampel } \\
\text { (Rp/th) }\end{array}$} & \multirow[b]{2}{*}{$\begin{array}{c}\% \text { Petani } \\
\text { Sampel (\% } \\
\text { Xi) }\end{array}$} & \multicolumn{5}{|c|}{ Kumulatif } \\
\hline & & & $\begin{array}{c}\text { Kumulatif } \\
\text { \% Petani } \\
\text { Sampel } \\
\text { (Kum. \% } \\
\text { Xi) }\end{array}$ & $\begin{array}{c}\% \text { Total } \\
\text { Pendapatan } \\
\text { Petani } \\
\text { Sampel } \\
(\% \mathrm{Yi})\end{array}$ & $\begin{array}{c}\% \\
\text { Pendapatan } \\
\text { Petani } \\
\text { Sampel } \\
\text { (Kum. \% } \\
\text { Yi) }\end{array}$ & $\begin{array}{c}\%(\mathrm{Yi}+ \\
\mathrm{Yi}-1)\end{array}$ & $\begin{array}{c}{[\% \mathrm{Xi}] \times} \\
{[\%(\mathrm{Yi}+} \\
\mathrm{Yi}-1)]\end{array}$ \\
\hline Terendah & 1.128 .580 & $5,56 \%$ & $5,56 \%$ & $0,22 \%$ & $0,22 \%$ & $0,22 \%$ & $0,01 \%$ \\
\hline Tertinggi & 248.971 .680 & $5,56 \%$ & $100,00 \%$ & $48,50 \%$ & $100 \%$ & $72,45 \%$ & $4,03 \%$ \\
\hline Total & 513.292 .540 & $100 \%$ & $950 \%$ & $100 \%$ & $423,53 \%$ & $247,99 \%$ & $13,79 \%$ \\
\hline Rata-rata & 28.516 .252 & $5,56 \%$ & $52,78 \%$ & $5,56 \%$ & $23,55 \%$ & $13,79 \%$ & $0,73 \%$ \\
\hline
\end{tabular}

Sumber : Data primer diolah, 2019. 


\section{Kurva Lorenz}

$\mathrm{GR}=\mathbf{0 , 8 6}$

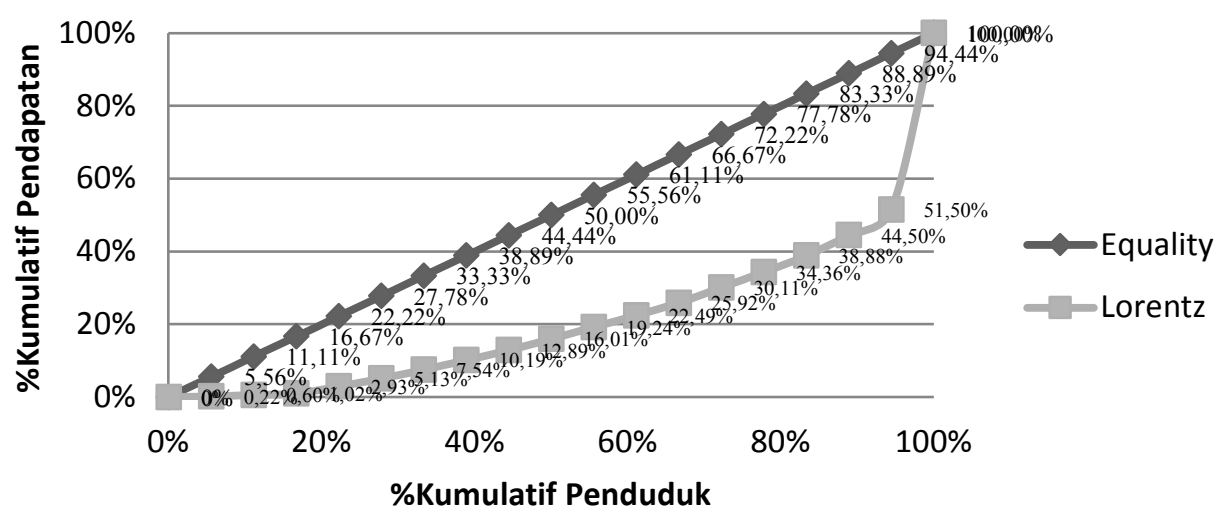

Gambar 2. Kurva Lorenz di Kecamatan Kedungbanteng. Sumber: Data primer diolah, 2019.

\section{Distribusi Pendapatan}

Total pendapatan rumah tangga petani sayur organik di kecamatan Kedungbanteng akan menentukan terjadinya pemerataan pendapatan atau ketimpangan pendapatan menggunakan analisis distribusi pendapatan. Ketimpangan pendapatan merupakan ketidakmerataan pendapatan yang diperoleh oleh setiap orang maupun rumah tangga dari berbagai usaha yang dijalankan (Murtisari, 2015). Menurut Shinta (2011), distribusi pendapatan dianalisis dengan metode koefisien Gini dan kurva Lorenz. Penggunaan kurva Lorenz akan lebih informatif dalam menerangkan hubungan antara proporsi pendapatan yang didistribusikan pada populasi yang ada, dan dengan bantuan kurva tersebut bisa didapatkan nilai koefisien Gini. Nilai koefisien Gini dapat dilihat pada Tabel 3. Gini Ratio $=1-[\% \mathrm{Xi}]$ x [\% $(\mathrm{Yi}+\mathrm{Yi}-1)]$

$$
=1-13,79 \%
$$$$
=86,21 \% \text { atau } 0,86
$$

Tabel 3 menunjukkan total pendapatan rumah tangga petani rata-rata dalam satu tahun adalah Rp 28.516.252,00 dengan pendapatan tertinggi yaitu $\mathrm{Rp}$ 248.971.680,00 dan pendapatan terendah yaitu Rp 1.128.580,00. Nilai Gini Ratio diperoleh sebesar 86,2 persen atau 0,86 artinya ketimpangan tingkat pendapatan petani sayur organik di kecamatan Kedungbanteng tinggi. Kriteria pengambilan keputusan adalah (Todaro et al., 2003):

1. Ketimpangan rendah, jika nilai GR lebih kecil dari 0,4

2. Ketimpangan sedang, jika nilai GR adalah antara 0,4 dan 0,5

3. Ketimpangan tinggi, jika nilai GR lebih dari 0,5 .

Hasil perhitungan menggunakan Indeks Gini dapat digambarkan kedalam 
sebuah grafik untuk melihat distribusi secara menyeluruh, kurva tesebut disebut Kurva Lorentz (Todaro et al., 2003). Kurva Lorenz yang terbentuk dari nilai Gini Ratio tersebut dapat dilihat pada Gambar 2. Gambar 2 menunjukkan adanya ketimpangan pendapatan yang tinggi, karena ada jarak antara kurva Lorenz dan garis diagonal (garis pemerataan). Hasil perhitungan nilai gini rasio distribusi pendapatan rumah tangga responden di kecamatan Kedungbanteng, menunjukkan nilai gini rasio sebesar 0,86 . Nilai gini rasio tersebut lebih dari 0,5 hasil perhitungan menunjukkan ketimpangan distribusi pendapatan antar responden dalam kategori tinggi (Todaro et al., 2003). Tingginya ketimpangan distribusi pendapatan antar petani tersebut menandakan bahwa distribusi pendapatan cenderung tidak merata antar petani responden di lokasi penelitian.

Menurut Permadi (2016), tingginya tingkat ketimpangan dan belum meratanya pendapatan yang diterima petani disebabkan oleh beberapa hal. Pertama yaitu masih sempitnya lahan yang dikuasai petani, harga yang diterima oleh petani tidak selalu sesuai dengan harapan, bahkan pada saat tertentu harga bisa sangat anjlok namun harga bisa sangat menguntungkan. Ketidakpastian harga ini yang menyebabkan pendapatan petani tidak menentu. Kedua adalah mayoritas petani responden hanya sedikit yang memiliki pekerjaan sampingan. Petani di daerah penelitian mengandalkan usahatani sayuran sebagai sumber mata pencaharian meskipun terkadang memiliki harga yang tidak pasti. Beberapa hal tersebut merupakan kendala yang harus ditanggulangi untuk mengurangi ketimpangan pendapatan petani di kecamatan Kedungbanteng.

\section{Tingkat Kesejahteraan}

Kesejahteraan masyarakat dapat diukur menggunakan NTPRP (Nilai Tukar Pendapatan Rumah Tangga Petani) dengan membandingkan antara pendapatan total rumah tangga petani dengan pengeluaran total rumah tangga petani. Menurut Yulian (2016), NTPRP yang digunakan sebagai tolak ukur kesejahteraan rumah tangga petani adalah apabila angka NTPRP kurang dari satu artinya tingkat kesejahteraan rumah tangga petani masih belum masuk kategori sejahtera. Namun jika angka NTPRP lebih dari satu artinya tingkat kesejahteraan rumah tangga petani masuk kategori sejahtera. Pendapatan dan pengeluaran rumah tangga petani sayuran organik di kecamatan Kedungbanteng dapat dilihat pada Tabel 4.

Tabel 4 menunjukkan pendapatan dan pengeluaran yang diperoleh rumah tangga petani sayuran organik di kecamatan Kedungbanteng dalam satu tahun dengan total pendapatan yang dinyatakan dengan (Y) rata-rata sebesar Rp 39.678.861,00 dan 
Tabel 4. Tingkat kesejahteraan petani sayuran organik di kecamatan Kedungbanteng dalam $\mathrm{Rp} /$ tahun

\begin{tabular}{lcccccc}
\hline Uraian & $\begin{array}{c}\text { Penerimaan } \\
\text { Usahatani } \\
(Y p)\end{array}$ & $\begin{array}{c}\text { Penerimaan } \\
\text { Non } \\
\text { Usahatani } \\
(\text { Ynp })\end{array}$ & $\begin{array}{c}\text { Pengeluaran } \\
\text { Usahatani } \\
(\text { Ep) }\end{array}$ & $\begin{array}{c}\text { Pengeluaran } \\
\text { Non } \\
\text { Usahatani } \\
(\text { Ek) }\end{array}$ & $\begin{array}{c}\text { Total } \\
\text { Penerimaan } \\
(Y)\end{array}$ & $\begin{array}{c}\text { Total } \\
\text { Pengeluaran } \\
(\mathrm{E})\end{array}$ \\
\hline Total & 378.219 .500 & 336.000 .000 & 12.118 .960 & 181.808 .000 & 714.219 .500 & 200.926 .960 \\
Rata-rata & 21.012 .194 & 18.666 .667 & 673.276 & 10.489 .333 & 39.678 .861 & 11.162 .609 \\
\hline
\end{tabular}

Sumber: Data primer diolah, 2019.

total pengeluaran $(\mathrm{E})$ rata-rata sebesar $\mathrm{Rp}$ 11.162.609,00. Menurut Yulian (2016), rumus untuk menghitung nilai tukar pendapatan rumah tangga petani (NTPRP) yaitu $\mathrm{Y} / \mathrm{E}$ atau total pendapatan dibagi total pengeluaran. Sehingga dapat dihitung NTPRP pada petani sayuran organik di kecamatan Kedungbanteng:

$$
\begin{aligned}
\text { NTPRP } & =\text { Y/E } \\
& =39.678 .861 / 11.162 .609 \\
& =3,55
\end{aligned}
$$

Angka NTPRP dapat diketahui yaitu sebesar 3,55 yang berarti hasil perhitungan NTPRP lebih dari satu, artinya tingkat kesejahteraan rumah tangga petani sayuran organik di kecamatan Kedungbanteng masuk kedalam kategori sejahtera. Hal tersebut dikarenakan total pendapatan lebih besar daripada total pengeluaran rumah tangga petani organik di kecamatan Kedungbanteng. Rumah tangga petani sayuran organik di kecamatan Kedungbanteng dapat memenuhi kebutuhan sehari-hari dengan total pendapatan rumah tangga yang diperoleh.
Menurut Rohmah et al. (2014), analisis kesejahteraan dilakukan untuk mengetahui keadaan ekonomi rumah tangga petani yang diperhitungkan dengan cara menghitung pendapatan dan pengeluaran rumah tangga untuk memperlihatkan bagaimana tingkat kesejahteraan tersebut. Pendapatan yang diperoleh petani sayur organik di kecamatan Kedungbanteng dalam memenuhi kebutuhan rumah tangganya berasal dari pendapatan total rumah tangga yang meliputi pendapatan usahatani sayuran organik, pendapatan usahatani diluar sayur organik, dan pendapatan diluar kegiatan usahatani.

\section{KESIMPULAN}

1. Besar pendapatan usahatani yang diterima petani yaitu $\mathrm{Rp} 7.892 .252,00$ per tahun dan kontribusi pendapatan usahatani sayuran organik terhadap pendapatan total yaitu sebesar 20,23 persen.

2. Tingkat pemerataan pendapatan petani sayuran organik di kecamatan 
Kedungbanteng termasuk dalam ketimpangan yang tinggi yaitu pendapatan petani yang tidak merata dengan nilai Gini Ratio 0,86.

3. Tingkat kesejahteraan rumah tangga petani sayuran organik di kecamatan Kedungbanteng masuk kedalam kategori sejahtera yaitu dengan NTPRP 3,55 .

\section{DAFTAR PUSTAKA}

Badan Pusat Statistik. 2019. Statistik Kesejahteraan. Badan Pusat Statistik.

Bhastoni, K. 2015. Peran wanita tani di atas usia produktif dalam usahatani sayuran organik terhadap pendapatan rumah tangga di desa Sumberejo kecamatan Batu. Jurnal Habitat, 6(2): 119-129.

Keumala, C.M., Z. Zainuddin. 2018. Indikator kesejahteraan petani melalui nilai tukar petani (NTP) dan pembiayaan syariah sebagai solusi. Economica: Jurnal Ekonomi Islam, (9)1: $129-149$.

Khorniawati, M. 2014. Produk pertanian organik di Indonesia: tinjauan atas preferensi konsumen Indonesia terhadap produk pertanian organik lokal. Jurnal Studi Manajemen, 8(2): 171-182.

Minarni, E.W., D.S. Utami, N. Prihatiningsih. 2017. Pemberdayaan kelompok wanita tani melalui optimalisasi pemanfaatan pekarangan dengan budidaya sayuran organik dataran rendah berbasis kearifan lokal dan berkelanjutan. Jurnal Pengabdian dan Pemberdayaan Masyarakat, 2(1): 147-154.

Murtisari, A. 2015. Pendapatan, sumber dan distribusi pendapatan rumah tangga petani jagung di kabupaten Bone
Bolango. Jurnal Perspektif Pembiayaan dan Pembangunan Daerah, (2)3: 129-134.

Permadi, Y. 2016. Distribusi pendapatan rumah tangga dan kesejahteraan petani sayur di desa Simpang Kanan kecamatan Sumberejo kabupaten Tanggamus. JIIA., 4(2): 145-151.

Rohmah, W., A. Suryantini, S. Hartono. 2014. Analisis pendapatan dan tingkat kesejahteraan rumah tangga petani tebu tanam dan keprasan di kabupaten Bantul. Jurnal Agro Ekonomi, 24(1): 54-65.

Shinta, A. 2011. Ilmu Usahatani. Universitas Brawijaya Press, Malang.

Sukayat, Y., D. Supyandi. 2017. Perilaku pemuda desa dalam kegiatan pertanian (beberapa kasus pemuda desa di agroekosistem dataran tinggi, dataran medium dan dataran rendah). Jurnal Ilmu Pertanian dan Peternakan, 5(1): 49-55.

Sutarni. 2017. Preferensi konsumen terhadap atribut produk sayuran organik di Kota Bandar Lampung. Jurnal Penelitian Pertanian Terapan, 17(3): 203-211.

Todaro, P. Micheal, dan S.C. Smith. 2003. Pembangunan Ekonomi di Dunia Ketiga. Erlangga, Jakarta.

Wahyuni, D. 2017. Penguatan kelembagaan petani menuju kesejahteraan petani. Jurnal Kesejahteraan Sosial, 9(17): 9-12.

Wardie, J. 2015. Analisis pendapatan dan kesejahteraan petani padi lokal lahan pasang surut di Kapuas. Jurnal Agros., 17(2): 153-165.

Yulian, R. 2016. Nilai tukar pendapatan rumah tangga petani agroforestri di hutan kemasyarakatan bina wana jaya di kesatuan pengelolaan hutan lindung Batutegi kabupaten Tanggamus. Jurnal Sylva Lestari, 4(10): 39-50. 
p-ISSN: 1410-0029; e-ISSN2549-6786

Agrin Vol. 24, No. 1, April 2020

Yulida, R. 2012. Kontribusi usahatani lahan pekarangan terhadap ekonomi rumah tangga petani di kecamatan Kerinci kabupaten Pelalawan. Indonesian Journal of Agricultural Economics, 3(2): 135-154. 